\title{
DEBT AND BONDAGE RECORDS \\ OF THE JOSEPH-VOLOKOLAMSK MONASTERY AS A SOURCE FOR STUDYING MONASTIC BORROWERS IN THE MIDDLE OF THE TIME OF TROUBLES (1606-1609)
}

\author{
Evgeniya S. Tseluykina \\ Volgograd State University, Volgograd, Russian Federation
}

\begin{abstract}
Introduction. To study the peasantry of the $16^{\text {th }}$ - the early $17^{\text {th }}$ century in Russia we need information from all the territories of the state. There are unique documents in the archives of the Joseph-Volokolamsk monastery for the central part of the Russian state, which allow us to investigate the issue of monastic enslavement. This issue has not been studied enough regarding the early $17^{\text {th }}$ century. Methods and materials. Such a source as a borrowed monastic bondage is poorly studied in historiography. In this regard the aim of the article is to study the position of monastery borrowers according to the form of debt records of the early $17^{\text {th }}$ century. There are objectives: to identify the elements of the form of bondage records that reflect the position of the borrowers; to consider changes in the position of borrowers based on the debt book form evolution. The article uses the methods of formal and comparative analysis with respect to records in debt books of 7115 (1606/07), $7116(1607 / 08)$, the bondage book of 1609, and borrowed bondages of 1609. Analysis. The records of money issuance debt books of 1606/07 and 1607/08 were compared with the information from the debt book of 1532-1534. The author traced the evolution of debt charging book design elements based on the sources of 1606/07 and 1607/08. The paper analyzes borrowed bondages of besieged people on borrowed monastery bread in 1609, along with the bondage book of 1609 . These results were compared with the bread bondages of the Spaso-Prilutsky monastery. Results. The form of debt records has been well developed by the early $17^{\text {th }}$ century. According to money issuance and charge records, a borrower was protected from lender's abuses. However, bread bondages most objectively reflect the position of a debtor, who was in danger of enslavement because of vague wording in bondages.

Key words: the Time of Troubles, Joseph-Volokolamsk monastery, debt book, bondage book, borrowed bondage, form analysis.

Citation. Tseluykina E.S. Debt and Bondage Records of the Joseph-Volokolamsk Monastery as a Source for Studying Monastic Borrowers in the Middle of the Time of Troubles (1606-1609). Vestnik Volgogradskogo gosudarstvennogo universiteta. Seriya 4, Istoriya. Regionovedenie. Mezhdunarodnye otnosheniya [Science Journal of Volgograd State University. History. Area Studies. International Relations], 2019, vol. 24, no. 2, pp. 62-75. (in Russian). DOI: https://doi.org/10.15688/jvolsu4.2019.2.7
\end{abstract}

ДОЛГОВЫЕ И КАБАЛЬНЫЕ ЗАПИСИ ИОСИФО-ВОЛОКОЛАМСКОГО МОНАСТЫРЯ КАК ИСТОЧНИК ДЛЯ ИЗУЧЕНИЯ МОНАСТЫРСКИХ ЗАЕМЩИКОВ В РАЗГАР СМУТНОГО ВРЕМЕНИ (1606-1609)

\author{
Евгения Сергеевна Целуйкина
}

Волгоградский государственный университет, г. Волгоград, Российская Федерация 
Аннотация. Для изучения крестьянства XVI - начала XVII в. в России необходимы сведения со всех ее территорий. В архиве Иосифо-Волоколамского монастыря сохранились уникальные для центральной части Русского государства документы, которые позволяют исследовать вопрос монастырского закабаления, недостаточно изученный для начала XVII века. Такой источник, как заемные монастырские кабалы, является слабо проработанным в историографии. В связи с этим цель статьи - раскрыть положение заемщиков монастыря по сведениям формуляра долговых записей начала XVII века. Задачи: выявить элементы формуляра кабальных записей, которые отражают положение заемщиков; рассмотреть изменения в положении заемщиков на основе эволюции формуляра долговых книг. В процессе исследования использованы методы формулярного и сравнительного анализа в отношении записей в долговых книгах 7115 (1606/07) г., 7116 (1607/08) г., кабальной книги 1609 г. и заемных кабал за 1609 год. Записи долговых книг выдачи денег за 1606/07 и 1607/08 гг. были сопоставлены со сведениями долговой книги за 1532-1534 годы. Прослежена эволюция элементов оформления долговой книги сбора денег на основе источников за 1606/07 и 1607/08 годы. Были проанализированы заемные кабалы осадных сидельцев на взятый монастырский хлеб 1609 г. наряду с кабальной книгой 1609 г., полученные результаты сопоставлены с хлебными кабалами Спасо-Прилуцкого монастыря. Формуляр долговых записей оказался хорошо проработанным к началу XVII века. По записям выдачи и сбора денег заемщик был защищен от злоупотреблений ссудодателя. При этом хлебные кабалы наиболее объективно отражают положение должника, который подвергался опасности закабаления из-за расплывчатых формулировок в кабалах.

Ключевые слова: Смутное время, Иосифо-Волоколамский монастырь, долговая книга, кабальная книга, заемная кабала, формулярный анализ.

Цитирование. Целуйкина Е. С. Долговые и кабальные записи Иосифо-Волоколамского монастыря как источник для изучения монастырских заемщиков в разгар Смутного времени (1606-1609) // Вестник Волгоградского государственного университета. Серия 4, История. Регионоведение. Международные отношения. 2019. - T. 24, № 2. - C. 62-75. - DOI: https://doi.org/10.15688/jvolsu4.2019.2.7

Введение. Иосифо-Волоколамский монастырь в начале XVII в. имел большое количество пахотных земель (в конце XVI в. около 26 тыс. десятин [51, с. 93]; ко второй четверти XVII в. - около 35 тыс. десятин [2, c. 43]) и крестьян, обрабатывавших их (на 1533 г. зафиксированы 670 крестьян из 202 селений [42, с. 92]). Близость к Москве и длительные исторические связи с государственной властью обусловили важную роль обители в политической истории России.

Проблема закабаления российского крестьянства в XVI в. является актуальной для исторической науки и в настоящее время. Получение сведений о положении заемщиков, которые брали ссуду в Иосифо-Волоколамском монастыре, поможет в дальнейшем продвинуться в решении вопроса о закрепощении монастырских крестьян начала XVII века.

Методы и материалы. Вопрос истории крестьянского кредитования Иосифо-Волоколамского монастыря по отношению к XVI в. хорошо изучен М.Н. Тихомировым и А.А. Зиминым был издан фрагмент одной из самых ранних из дошедших до нас хозяйственных книг - Долговая книга 1532-1534 годов [34]. Она стала источником для изучения обители как вотчины, исследования социально-экономических процессов внутри обители, форм взаимодействия администрации монастыря с крестьянами $[48 ; 27]$ и процесса кредитования [42; 44].

В советской историографии изучены реформы казначея старца Мисаила Безнина 1591 г., последовавшие за ними восстание крестьян и изгнание старца из обители. Первым этот вопрос поднял К.Н. Щепетов. Его работа, посвященная сельскому хозяйству монастыря в конце XVI в., стала первым исследованием, где объектом изучения была сама обитель [51]. Автор ввел в научный оборот приходо-расходные книги 1580-1590-х гг., охарактеризовал кредитование как принудительное и дал ему негативную оценку. И.И. Смирнов в статье о восстании И. Болотникова, а затем и в монографии рассмотрел волнения крестьян в ИосифоВолоколамском монастыре 1590-х гг. как предвестник восстания И. Болотникова, которое является ярким примером социально-экономического кризиса, назревшего в государстве в конце XVI века [45; 46]. В.И. Корецким было доказано более раннее существование кредитования в монастыре и выяснено значение этого явления для закрепощения крестьян [35]. 
Изучение формуляра служилых кабал далеко продвинулось благодаря работам B.M. Панеяха [39; 40; 41]. С.М. Каштанов внес весомый вклад в исследование формуляра актового материала монастырского происхождения [31]. Формуляр жалованных грамот Иосифо-Волоколамского монастыря был отчасти рассмотрен А.А. Зиминым [28].

В ряде работ монастырские кабалы используются в качестве исторического источника, но их не так много $[31 ; 1 ; 32]$. Особое значение для нашего исследования имеет монография М.М. Дадыкиной, в основе которой лежат кабалы Спасо-Прилуцкого монастыря XVI-XVII веков [4]. Изучив формуляр денежных и хлебных кабал, исследователь проследила эволюцию формирования крестьянского кредитования в Спасо-Прилуцком монастыре. Сопоставление формуляров кабал Иосифо-Волоколамского и Спасо-Прилуцкого монастырей позволяет полнее воссоздать картину крестьянского монастырского кредитования начала XVII века.

Таким образом, видно, что ученые обращались к традициям монастырского кредитования, но большей частью для исследования событий XVI в. (в частности, закабаления в Иосифо-Волоколамском монастыре до 1590-х годов). Период Смутного времени лишь предстоит рассмотреть.

В связи с этим цель статьи - раскрыть положение заемщиков монастыря по сведениям формуляра долговых записей начала XVII века. Для этого, на наш взгляд, необходимо выявить элементы формуляра кабальных записей, которые отражают положение заемщиков; рассмотреть изменения в положении заемщиков на основе эволюции формуляра долговых книг.

Нами использованы документы официального делопроизводства монастыря - Приходо-расходная книга за $7115(1606 / 07)$ г. [49], Приходо-расходная книга за $7116(1607 / 08)$ г. [43], Кабальная книга 1609 г. [29], - и актовый материал - около 500 заемных кабал осадных сидельцев 1609 года [6-26]).

Основным методом в исследовании стал формулярный анализ. Наличие большого числа актового материала позволило при помощи формулярного анализа изучить структуру грамот. Также метод сравнительного анали- за использован при сопоставлении сведений Долговой книги 1532-1534 гг., Приходо-расходной книги 1606/07 г. с данными 1607/08 года.

Анализ. Первые известные историкам кабалы относятся к XIV в., письменно они оформлялись уже с середины XVI в., а к концу столетия сложился их формуляр [4, с. 12]. Как отмечает С.М. Каштанов, по мнению некоторых исследователей, монастыри, обладая большими вотчинными землями, являлись продолжателями рабовладельческой традиции как «естественное следствие власти “домовладыки и отца"» [30, с. 184]. В связи с этим представляется интересным и закабаление крестьян. Наиболее исследованным аспектом кабальной проблемы является кабальное холопство, но его нельзя отождествлять с кабальными монастырскими людьми. Н.П. Павлов-Сильванский провел различия между кабальными людьми и кабальными холопами: до Уложения о холопах 1597 г. кабальные люди были свободными, по служилым кабалам они работали на помещика, пока не выплатят долг. В заемных кабалах они называли себя «заимщиками», в Судебнике 1550 г. использовалось понятие «серебряники» [38]. Б.Д. Греков также считал, что кабальные люди не относились к холопам, а были вольными даже после Уложения 1597 г. [3, с. 114].

Понимание разницы между положением холопа, попавшего в зависимость по кабале, и крестьянина, взявшего в долг, принципиально важно. Выделять Уложение 1597 г. как четкую границу, после чего все кабальные люди стали холопами, нужно крайне осторожно. По признанию Н.П. Павлова-Сильванского, с самого начала появления кабальной зависимости «заимщики» находились в правовом положении холопов, так как использовались на тех же работах. Их служба была в основном потомственная, а не посмертная [38], выход из такого состояния был практически невозможен из-за ростового характера сделки [37]. Все это сближает кабального человека с холопом. При этом на официальном уровне строго придерживались понимания кабальных людей как свободных, что подтверждается указом Василия Шуйского от 6 марта 1608 г. со ссылкой на Судебник 1550 г.: в нем запрещалось записывать кабальных людей в одни списки с холопами [50; 3 , с. 114]. 
Монастырские крестьяне в аспекте проблемы закабаления представляют собой особенную категорию населения. Если правовое положение кабальных людей регулировалось Судебником 1550 г. и множеством указов, которые позже вошли в сводный Судебник 1606/07 г., то отношения между монастырем и его крестьянами, как отметил И.К. Смолич, строились на основе жалованных и несудимых грамот, а также самих кабал [47]. Анализ исследователями жалованных грамот показал, что ни в «иммунитетной» [31], ни в «вотчинной» части документов не содержится информации об экономических взаимоотношениях монастыря и крестьян [28].

Важно отметить, что для Иосифо-Волоколамского монастыря понятие кабала было приближено к понятию долг, так как в источниках начала XVII в., названия которых обозначены не иначе как «Долговые книги», речь идет о кабалах («на кобале подписано», «и кобала ему выдана» и пр.). Также стоит сказать о том, что долговые и кабальные книги являются частью хозяйственных приходо-расходных книг [36, с. 289]. Подтверждением этому становится тот факт, что долговые книги сшиты с приходными, расходными и другими видами книг за один и тот же год в одну тетрадь. В итоге кабала в монастырском хозяйстве середины XVI - начала XVII в. - это не столько наследственное ярмо, как у кабальных холопов, сколько форма ссуды.

Сама обитель имела довольно длительную традицию кредитования. Долговая книга за 1532-1534 гг. - один из самых ранних делопроизводственных документов монастырского происхождения, дошедших до нас (самой древней считается расходная книга Псковской Завеличской церкви 1531 г.) [34; 36, c. 287]. Здесь зафиксированы выдачи денег крестьянам - жителям вотчины, принадлежавшим соседним вотчинникам [44, с. 35]. В основном эти записи характеризуются как подможные, то есть займ был не краткосрочный, вернуть долг нужно было до ухода крестьянина из вотчины [42, с. 92]. Наличие такого источника делает возможным не только изучение жизни монастырских крестьян в первой половине XVI в., но и рассмотрение феномена монастырского кредитования в развитии.
В начале XVII в. были составлены две приходо-расходные книги, в которых содержались по две долговые книги (книга сбора и книга выдачи денег), также сохранилась кабальная книга, которая, предположительно, тоже входила в состав приходо-расходной. Итого имеется пять долговых книг: 1) Долговая книга $7115(1606 / 07)$ г. (записи с 22 апреля 1607 г.) - ведомости сбора денег по кабалам [49, с. 334-338]; 2) Долговая книга 7115 (1606/07) г. - данные о деньгах, выданных крестьянам в долг [49, с. 362-365]; 3) Долговая книга $7116(1607 / 08)$ г. - сборы денег с крестьян по кабалам [43, л. 53-83 об.]; 4) Долговая книга 7116 (1607/08) г. - выдача денег в кабалу на лошадей [43, л. 232-234]; 5) Кабальная книга 1609 г. - данные о выдаче хлеба в долг [29]. Также около 500 заемных кабал на монастырский хлеб за 1609 год [6-26]. Сравним условный формуляр записей из долговых и кабальной книг и кабал.

В долговой книге выдачи денег за 1606/07 г. записи располагались по хронологии: первая выдача за день была написана с датой, все остальные уже без. Следующую позицию занимало географическое положение - название села, деревни, после чего - сведения о заемщике, ссуде и диспозиция, которая в нашем случае обозначается словами «и кобала на него взята».

Такая подробная запись должников берет свое начало еще с первой половины XVI века. В Долговой книге 1532-1534 гг. имена заемщиков располагались под названием сел, деревень или починков, в которых они проживали [34, с. 117]. В книгу были внесены имена не только тех крестьян, которые взяли ссуду, но и членов их семей. В течение следующего года к долговым записям были сделаны приписки, свидетельствовавшие о судьбе займа [42, с. 92].

В долговой книге 1606/07 г. уже нет росписи семьи заемщика. Этот факт можно связать с несколькими аспектами. Во-первых, как отметил М.А. Дьяконов, правовое положение старожильцев, которые в начале XVII в. составляли большинство крестьян, не позволяло им покидать вотчину [5, с. 16-39]. Из этого следовало отсутствие необходимости в тотальном контроле за большим числом крестьян, поскольку уйти они не могли. Во-вторых, систе- 
ма сельских приказов во главе с сельскими старостами к данному моменту уже была хорошо отработана. Староста с подвластными ему целовальниками, приказчиками и прочими знал население своего приказа, так как каждый год вел учетную запись взимания налогов, податей, долгов. Вероятно, староста лично был знаком с каждым крестьянином.

В книге выдачи денег в кабалу 1607/08 г. была продолжена схема, которая закрепилась в долговой книге первой половины - середины XVI в.: записи не имели дат, располагались по географическому принципу, но данные о членах семьи заемщика не были внесены в текст. В этой книге содержится лишь одна дата - 1 сентября 1607 г., когда казначею старцу Гавриле была выдана «память» игуменом и соборными старцами на раздачу денег [43, л. 232].

В долговой книге сбора денег по кабалам за 1606/07 г. информация была зафиксирована на основе территориального признака в первую запись было внесено полное название села, а в последующих использовалась устоявшаяся формулировка «Тово ж села». При этом обязательно была указана деревня, к которой относились крестьяне. В итоге каждая позиция в книге выглядела следующим образом: село, деревня, заемщик, ссуда и диспозиция («на кобале подписана» - если долг возвращен не полностью, «и кобала ему выдана»-если долг уплачен).

В долговой книге сбора денег по кабалам за 1607/08 г. записи по структуре напоминают те, что были сделаны годом ранее. Разница состоит в том, что в книге 1607/08 г. они были расположены не по географическому признаку, а по дате, которая не зафиксирована в книге прошлого года.

В целом можно отметить расширение обязательного формуляра долговых записей в книге нашли отражение социальное положение должника и год написания на него кабалы. При этом запись о его географической принадлежности упростилась. Эти изменения можно проследить наглядно (табл. 1). В итоге произошла оптимизация формуляра. Включение даты говорит об упорядочивании хозяйственных записей. Социальное положение заемщика - это включение, которое особенно хорошо продемонстрировало свою важность в следующем году, когда кроме крестьян в долг начали брать представители различных категорий населения монастыря. Информация о годе написания кабалы также служила делопроизводственным нуждам, так как облегчала поиск кабал; также это позволяло узнать, какой казначей выдал деньги в долг.

Особое место занимают хлебные кабалы 1609 года. Кабальная книга включает в себя очень простые записи, которые, скорее всего, были переписаны с кабальных грамот для ведения учета. Здесь элементы формуляра располагались следующим образом: «Кабола» - обозначение вида записи, имя заемщика, его социальное положение или должность, его принадлежность помещику (если была), географическое положение, ссуда и дата. Ярким примером может служить такая запись в книге: «Кабола Кирила да Осипа Фомины дети кр[е]стьяне Александра Андреевича Нагова села Порфенева занели три четверики ржи да три четверики жита июня въ 4 д[е]нь» [29, л. 1].

Таблиц̧а 1

Сравнение формуляров записей долговой книги сбора денег с крестьян по кабалам за 1606/07 г. и долговой книги сбора денег с крестьян по кабалам за 1607/08 г.

\begin{tabular}{|l|l|l|}
\hline \multicolumn{1}{|c|}{ Элементы формуляра } & \multicolumn{1}{|c|}{ Долговая книга 1606/07 г. } & \multicolumn{1}{|c|}{ Долговая книга 1607/08 г. } \\
\hline Дата & - & Того ж м[е]с[я]ца въ 16 д[е]нь \\
\hline $\begin{array}{l}\text { Географическое положе- } \\
\text { ние }\end{array}$ & Села Лествицына деревни Кузяева & на быко вскомъ \\
\hline $\begin{array}{l}\text { Социальное положение } \\
\text { заемщика }\end{array}$ & - & Крестьянине \\
\hline Заемщик & на Гришке Улитине сыне & на Лукаше Офремовском \\
\hline Ссуда & пол-полтины & полтина денег \\
\hline Диспозиция & и на кобале подписано & и кобала ему выдана \\
\hline Год написания кабалы & - & 112-го году \\
\hline
\end{tabular}

Примечание. Составлено по: [49, с. 334; 43, л. 54]. 
Необходимо обратить внимание на то, что назначение кабальной книги остается все еще не ясным. Если это была вариация долговой книги, тогда непонятно, почему записи располагались не по хронологии, а в целом напоминали переписанные кабалы. По нашему мнению, нельзя ставить ее в один ряд с долговыми книгами выдачи денег.

Заемные кабалы осадных сидельцев на взятый монастырский хлеб - это массовый источник. Необходимо помнить, что кабалы были написаны разными авторами с разным уровнем подготовки, поэтому выделить единый условный формуляр достаточно сложно.

Из начального протокола в тексте источников присутствует интитуляция «се яз...» и инскрипция «занял есми Пречистыя Богородицы Иосифова монастыря у житнишнава старца Леонида». Перед именем заемщика обычно указывалось его социальное положение или должность, после - принадлежность помещику (если была) и географическое положение. Основное содержание документа составляли диспозиция, санкция и корроборация. Диспозиция включала в себя ссуду и ее характер, обстоятельства займа (в нашем случае - осадное положение), сроки. Санкция (чаще всего отсутствовала вовсе): «а заплатит мне тот хлеб в монастыр <... тот час без срочна по сей кобале»; «а заплатит нам та рож в монастырскую житницу $<\ldots .>$ не отимаючи ни которыми делы». Корроборация состояла всегда из имени писца, реже перед ним добавлялись имена послухов.
Конечный протокол включал в себя только датум, чаще всего указание года: «...лета 7117-го году». Более точная дата содержалась в диспозиции. Некоторые писцы не писали и год. В качестве примера можно привести текст следующей кабалы: «Се яз поп Карпъ Дементеевъ с(ы)нъ Александра Андреевича Нагова села Парфенева занел есми у Пр(е)ч(и)стые Б(огороди)цы Иосифова м(о)н(a)стыря у житничнаго старца Корниля м(о)н(а)стырскаг(о) хлеба полосмины ржи да полосмины овса в осаде 117-го апреля въ 9 д(е)нь а заплатит мне тот хлеб как осадноя время минетца тот час а на то послух диячок Алексей Осипов с(ы)нъ Дурницын а кобалу писал Мокейко Исаев 117-го году» [25, л. 104].

М.М. Дадыкиной был проведен детальный анализ хлебных кабал Спасо-Прилуцкого монастыря. Сравнив формуляр заемных кабал на взятый хлеб Иосифо-Волоколамского монастыря с хлебными кабалами Спасо-Прилуцкого монастыря, можно более полно смоделировать положение заемщика (табл. 2).

Условные формуляры кабал двух монастырей действительно сильно схожи, но наблюдаются и отличия. Подробная роспись интитуляции в обоих случаях - необходимость для точного учета большого числа заемщиков. Инскрипция у Спасо-Прилуцкого монастыря довольно разнообразна, что объясняется возможностью займа не только в обители, но и у частных лиц. ИосифоВолоколамский монастырь в 1609 г. мог быть в этой местности единственным ссудодате-

Сравнение условных формуляров заемных кабал

Таблича 2

\section{Спасо-Прилуцкого и Иосифо-Волоколамского монастырей}

\begin{tabular}{|c|c|c|c|}
\hline \multicolumn{2}{|l|}{ Формуляр } & Кабалы Спасо-Прилуцкого монастыря & Кабалы Иосифо-Волоколамского монастыря \\
\hline \multicolumn{2}{|c|}{ Интитуляция } & + & + \\
\hline \multicolumn{2}{|c|}{ Обязательство } & + & + \\
\hline \multicolumn{2}{|c|}{ Инскрипция } & + & + \\
\hline \multirow{4}{*}{$\begin{array}{l}\text { Диспо зи- } \\
\text { ция }\end{array}$} & Ссуда & + & + \\
\hline & Дата & + & + \\
\hline & Срок & + & + \\
\hline & Poct & + & - \\
\hline \multicolumn{2}{|l|}{ Санкция } & + (7 вариантов) & + \\
\hline \multirow{2}{*}{$\begin{array}{l}\text { Корробо- } \\
\text { рация }\end{array}$} & Послух & + & + \\
\hline & Писец & + & + \\
\hline \multicolumn{2}{|l|}{ Датум } & + & + \\
\hline
\end{tabular}

Примечание. Составлено по: [4, с. 95-96; 6-26]. 


\section{ИСТОЧНИКОВЕДЕНИЕ}

лем в связи с осадным положением, в котором находилась обитель.

В диспозиции присутствует «рост»: в Спасо-Прилуцком монастыре деньги выдавали «в рост» либо «без росту». В Волоколамской обители в 1609 г. ростовые кабалы не зафиксированы. Это можно связать с двумя принципиальными моментами. Первый характеризуется реформами в сфере принудительного кредитования казначея старца Мисаила Безнина в конце XVI в., которые закончились сильными волнениями крестьян и изгнанием старца из вотчины. Второй основан на осадном положении, особенности которого вынуждали людей брать хлеб в долг из монастырских житниц несколько раз за полгода. Хлебные кабалы были способом продления жизни для всех осажденных.

Санкции в Спасо-Прилуцком монастыре также очень хорошо отображены в источниках, известны 7 клаузул, которые одновременно могли использоваться в кабале: о неустойке, о денежном росте, о делах и грамотах, о суде, об убытках, о нескольких заемщиках, об истце [4, с. 95]. В то же самое время в Иосифо-Волоколамском монастыре вся санкция ограничивалась двумя понятиями, которые семантически сводятся к единому: «сразу после снятия осады». Это значит, что система выплаты долга не была оформлена и заемщик оказывался незащищен перед ссудодателем. Именно это и было выгодно монастырю, который, хоть и имел неудачный опыт быстрого закабаления крестьян, продолжал использовать уже проверенный метод, но уже не экстенсивно, а интенсивно. Можно с уверенностью сказать, что это не было явлением только 1609 г., интенсивным закабалением характеризуется весь процесс долгового оборота начала XVII века. Это подтверждается большим количеством кабал, которые к этому моменту уже были розданы (например, в 1606/07 г. - 63 новые кабалы, в ходу было более 600 кабал [49, с. 365]). Монастырю, очевидно, было выгодно, чтобы долг оставался невыплаченным как можно дольше, а после смерти перешел к семье должника, так как в таком случае закабаленными оказывались большие крестьянские семьи. Эта тенденция была отмечена еще В.О. Ключевским по отношению и к другим монастырям [33]. Также необходимо принимать во внимание тот факт, что условия осадного времени не оставляли возможность для широкого применения санкционных мер, существовала неопределенность будущего заемщика.

Отметим, что одна из клаузул документа Спасо-Прилуцкого монастыря очень похожа на санкцию из кабалы Иосифо-Волоколамской обители: «И не отиматися нам заимщиком от сея кабалы никак, никоторыми делы, и государя жалованными грамотами, ни княжецкими, ни боярскими, ни митрополичьими, ни владычными» $[4$, с. 95] и «а заплатит мне та рож(ь) как Б(о)гъ даст осад минетца не отимаючи никоторыми делы» [25, л. 148]. Эта формулировка была довольно устойчивой для второй половины XVI-XVII в., поэтому нет ничего удивительного в том, что она использовалась в обоих монастырях.

Положение заемщиков ярче всего отражено в таких элементах формуляра заемных кабал, как диспозиция, санкция и корроборация. Наличие срока выплаты долга уже свидетельствовало о возможности выхода из кабального положения. При этом на деле такую запись невозможно однозначно интерпретировать: «как осад минетца тот час». Четкого срока выплаты нет, что ставит в невыгодное положение скорее самого заемщика, который был вынужден пойти на такие условия. Санкция также была не проработана. Формулировка «не отимаючи ни которыми делы» давала лишь указание на срочность возврата долга и исключала возможность избавления от него по указам сверху. Поэтому санкция также работала в пользу монастыря, запрещая заемщику каким бы то ни было образом отказываться от возврата хлеба.

Корроборационная часть, а именно послух, не была унифицирована. Послушество зафиксировано далеко не во всех кабалах, к тому же зачастую в качестве послуха выступал родственник заемщика. Необходимо отметить, что хлебные кабалы начала XVII в., выданные Спасо-Прилуцким монастырем, в большинстве так и не были выплачены. Мы пока не имеем сведений о судьбе займов, взятых в Иосифо-Волоколамском монастыре после окончания Смутного времени. Можно только высказать гипотезу о том, что здесь также большинство ссуд не 
было возвращено в первую очередь из-за разорения обители и ее вотчины.

Результаты. Кабалы Иосифо-Волоколамского монастыря содержат ценную информацию по социально-экономической истории вотчины. Наличие длительной истории фиксирования долговых отношений дает возможность проследить изменения в элементах формуляра кабальных записей.

При выдаче денег особое внимание уделялось месту жительства заемщика. Но если в XVI в. это было одним из главных признаков должника (когда крестьянин менял место жительства, это обязательно фиксировалось и в долговой книге [42, с. 95]), то в начале XVII в. акцент делался на дате выдачи денег. Роспись членов семей заемщиков в начале XVII в. уже не проводилась - большинство крестьян были старожильцами.

Записи сбора денег на протяжении 1606 1608 гг. также претерпели некоторые изменения. В формуляр были включены такие важные элементы, как дата взятия денег, дата составления кабалы, по которой деньги собраны, и социальное положение заемщика. Благодаря этому положение крестьянина, взявшего в долг, обрисовывалось более точно: было четкое указание на заемщика и его кабалу. Теперь крестьянину не смогли бы приписать чужой долг или взятый им в другое время.

Все эти достижения нашли отражение в Кабальной книге 1609 г., куда были внесены записи о раздаче хлеба. В данном источнике были зафиксированы основные элементы, которые изменялись в течение предыдущих лет: социальное положение заемщика (это были не только крестьяне), место жительства и дата выдачи займа. Теперь найти заемщика или кабалу не составляло труда.

Заемные кабалы осадных сидельцев на взятый хлеб Иосифо-Волоколамского монастыря содержат в себе все важные статьи условного формуляра кабалы. По сравнению со Спасо-Прилуцким монастырем санкционные статьи оказались самыми непроработанными, несмотря на их важность для правового регулирования.

Юридически заемщик изначально находился в долговом положении, он не имел возможности приобрести либо вырастить самостоятельно хлеб взамен взятого, так как должен был вернуть его сразу после снятия осады. Санкционные меры были сформулированы нечетко, несмотря на значимость этого элемента формуляра. Послушество, которое должно было придать сделке правовой характер, чаще лишь подчеркивало формальный характер сделки.

Таким образом, к началу XVII в. формуляр записей долговых книг был хорошо разработан. В целом информация о заемщике весьма скудна. При выдаче денег в долг и при сборе этих денег в записях долговых книг заемщик оказывался защищенным от ошибок и злоупотреблений монастырской администрации, так как все записи были зафиксированы. Но в хлебных кабалах правовое положение заемщика отражено наиболее объективно отсутствие четких формулировок подвергало должника, в частности, крестьянина, опасности закабаления, что и было выгодно обители. Это было тем более актуально, что кабалы являлись практически единственным регулятором взаимоотношений монастыря и крестьян, так как в жалованных и несудимых грамотах подобная информация не отложилась.

\section{СПИСОК ЛИТЕРАТУРЫ}

1. Бугров, А. В. Ссудные операции русских монастырей в XIV-XVII вв. / А. В. Бугров // Вестник Банка России. - 2004. - № 18 (742). - С. 31-35.

2. Водарский, Я. Е. Православные монастыри России и их роль в развитии культуры (XI - начало ХХ в.) / Я. Е. Водарский, Э. Г. Истомина - М. : ИРИ РАН, 2009. $-546 \mathrm{c}$.

3. Греков, Б. Д. Крестьяне на Руси с древнейших времен до середины XVII в. В 2 т. Т. 2 / Б. Д. Греков-М. : Изд-во АН СССР, 1954. - 470 с.

4. Дадыкина, М. М. Кабалы Спасо-Прилуцкого монастыря второй половины XVI - XVII вв. Исследование. Тексты / М. М. Дадыкина. - М. ; СПб. : Альянс-Архео, 2011. -384 с.

5. Дьяконов, М. А. Очерки из истории сельского населения в Московском государстве, XVIXVII вв. / М. А. Дьяконов. -2-е изд. - M. : URSS, 2011. - 348 c. - (Академия фундаментальных исследований: история).

6. Заемная кабала крестьянки Александра Андреевича Нагова с. Парфеньева Пелагеи Ивановой дочери, Савельевской жены келарю Корнилию на взятый хлеб во время осады // Российский государственный архив древних актов (РГАДА). Ф. 1192 (Иосифо-Волоколамский монастырь). Оп. 1, ч. 4. - Д. 2540. - Л. 1. 
7. Заемная кабала осадного сидельца монастырского крестьянина Даниила Матвеева Кузнеца житному старцу Корнилию на взятый монастырский хлеб // РГАДА. -Ф. 1192. - Оп. 1, ч. 4. - Д. 2248. Л. 1.

8. Заемная кабала осадного сидельца, посадского человека Волока Ламского, Златоустовской слободы Андрея Курьева на взятый хлеб из монастырских житниц // РГАДА. - Ф. 1192. - ОП. 1, ч. 4. Д. 2542. - Л. 1.

9. Заемные кабалы осадного сидельца Бажена Дмитриева Языкова келарю Корнилию на взятый хлеб // РГАДА. - Ф. 1192. - Оп. 1, ч. 4. - Д. 2529. Л. $1-4$.

10. Заемные кабалы осадного сидельца, крестьянина Внука Зиновьевича Тютчева сельца Курова Матвея Лукьянова на взятый хлеб из монастырских житниц // РГАДА. - Ф. 1192. - ОП. 1, ч. 4. Д. 2543 . - Л. 1-5.

11. Заемные кабалы осадных сидельцев - волоцких посадных людей сапожного мастера Федора Васильева и рассыльщика Фрола Васильева келарю Корнилию на взятый хлеб // РГАДА. Ф. 1192. - Оп. 1, ч. 4. - Д. 2531. - Л. 1.

12. Заемные кабалы осадных сидельцев - волоцких посадских людей - келарю Корнилию на взятый хлеб // РГАДА. - Ф. 1192. - Оп. 1, ч. 4. - Д. 2535. Л. 1-3.

13. Заемные кабалы осадных сидельцев - крестьян и деловых людей Александра Андреевича Нагова - келарю Корнилию на взятый хлеб // РГАДА. Ф. 1192. - Оп. 1., ч. 4. - Д. 2545 . - Л. 1-6.

14. Заемные кабалы осадных сидельцев - крестьян и посадских людей - келарю Корнилию на взятый хлеб // РГАДА. - Ф. 1192. - Оп. 1, ч. 4. Д. 2538. - Л. 1-4.

15. Заемные кабалы осадных сидельцев - крестьян Михаила Дмитриевича Телегина, крестьян Григория Ступишина с. Смолинского - келарю Корнилию на взятый хлеб // РГАДА. - Ф. 1192. - Оп. 1, ч. 4. - Д. 2537. - Л. 1-16.

16. Заемные кабалы осадных сидельцев - крестьян Михаила Телегина келарю Корнилию на взятый хлеб // РГАДА. - Ф. 1192. - Оп. 1, ч. 4. - Д. 2544. Л. $1-4$.

17. Заемные кабалы осадных сидельцев - крестьян Московского Новодевичьего монастыря келарю Корнилию на взятый хлеб // РГАДА. Ф. 1192. - Оп. 1, ч. 4. - Д. 2534. - Л. 1-4.

18. Заемные кабалы осадных сидельцев - крестьян Новодевичьего монастыря дер. Кротово, Коротымново, Олешина, с. Спасского, с. Покоина, с. Козино - келарю Корнилию на взятый хлеб // РГАДА. Ф. 1192. - Оп. 1, ч. 4. - Д. 2541. - Л. 1-13.

19. Заемные кабалы осадных сидельцев - крестьян Федора Иудовича Хрипунова - келарю Кор- нилию на взятый хлеб // РГАДА. - Ф. 1192. - Оп. 1, ч. 4. - Д. 2533. - Л. 1-8.

20. Заемные кабалы осадных сидельцев московского стрельца Семена Сергеева и волоцких посадских людей - келарю Корнилию на взятый хлеб // РГАДА. - Ф. 1192. - Оп. 1, ч. 4. Д. 2539. - Л. 1-7.

21. Заемные кабалы осадных сидельцев - священнослужителей, волоцких посадных людей, крестьян Андрея Тимофеевича Быкасова с. Теплова келарю Корнилию на взятый хлеб // РГАДА. Ф. 1192. - Оп. 1, ч. 4. - Д. 2536. - Л. 1-55.

22. Заемные кабалы осадных сидельцев детей боярских - волочанина Мелентия Константинова, дмитровца Григория Прокофьева сына Савина, ружан братьев Курвиных с тов. - келарю Корнилию на взятый хлеб // РГАДА. - Ф. 1192. - Оп. 1, ч. 4. - Д. 2532. - Л. 1-13.

23. Заемные кабалы осадных сидельцев келарю Корнилию и житничному старцу Леониду на взятый хлеб // РГАДА. - Ф. 1192. - Оп. 1, ч. 4. Д. 2527. - Л. 1-51.

24. Заемные кабалы осадных сидельцев крестьян Александра Андреевича Нагова с. Парфеньева келарю Корнилию на взятый хлеб // РГАДА. Ф. 1192. - Оп. 1, ч. 4. - Д. 2530. - Л. 1-13.

25. Заемные кабалы осадных сидельцев монастырским властям на занятый во время осады монастыря хлеб // РГАДА. - Ф. 1192. - Оп. 1, ч. 4. Д. 2526. - Л. 1-199.

26. Заемные кабалы осадных сидельцев-священнослужителей келарю Корнилию и житничному старцу Леониду на взятый хлеб // РГАДА. Ф. 1192. - Оп. 1, ч. 4. - Д. 2528. - Л. 1-6.

27. Зимин, А. А. Крупная феодальная вотчина и социально-политическая борьба в России в конце XV-XVI в. / А. А. Зимин. - М. : Наука, 1977. $356 \mathrm{c}$.

28. Зимин, А. А. О дипломатике жалованных грамот Иосифо-Волоколамского монастыря XVI в. / А. А. Зимин // Актовое источниковедение : сб. ст. М. : [б. и.], 1979. - С. 164-178.

29. Кабальная книга 1609 г. // Научно-исторический архив Санкт-Петербургского института истории РАН (НИАСПбИИ РАН). - Кол. 115. - Оп. 1. Д. 1037.-159 л.

30. Каштанов, С. М. Московское царство и Запад. Историографические очерки / С. М. Каштанов. - М. : Изд-во УН-та Дмитрия Пожарского, $2015-461 \mathrm{c}$.

31. Каштанов, С. М. Очерки русской дипломатики / С. М. Каштанов. - М. : Наука, 1970. -502 с.

32. Кириченко, Л. А. Актовый материал Троице-Сергиева монастыря 1584-1641 гг. как источник по истории землевладения и хозяйства / Л. А. Кириченко - М. : Изд-во РГГУ, 2006. - 288 с. 
33. Ключевский, В. О. Происхождение крепостного права в России / В. О. Ключевский // Собрание сочинений в 9 т. Т. 8. - М. : Мысль, 1990. C. $120-193$.

34. Книга ключей и долговая книга Иосифо-Волоколамского монастыря XVI в. / под ред. М. Н. Тихомирова и А. А. Зимина. - М. ; Л. : Изд-во АН СССР, 1948. - $172 \mathrm{c}$.

35. Корецкий, В. И. Закрепощение крестьян и классовая борьба в России / В. И. Корецкий. - М. : Наука, 1970. - $366 \mathrm{c}$.

36. Маньков, А. Г. Хозяйственные книги монастырских вотчин XVI в. как источник по истории крестьян / А. Г. Маньков // Проблемы источниковедения. - 1955. - Вып. IV. - C. 286-306.

37. Мухина, Ю. Ю. Характеристика положения крестьян и холопов в России во второй половине XVI-XVII вв. / Ю. Ю. Мухина // Вестник Московского государственного гуманитарного университета им. М.А. Шолохова. Серия «История и политология». - 2012. - № 2. - С. 5-14.

38. Павлов-Сильванский, Н. П. Государевы служилые люди. Люди кабальные и докладные / Н. П. Павлов-Сильванский. - [Б. м.]: Тип. М. М. Стасюлевича, 1909. - 336 с.

39. Панеях, В. М. Добровольное холопство в законодательстве XVI-XVII вв. (1550-1649 гг.) / В. М. Панеях // Исследования по социально-политической истории России : сб. ст. памяти Б. А. Романова. - Л. : Наука, 1971. - С. 198-216. - (Труды ЛОИИ АНСССР ; вып. 12).

40. Панеях, В. М. Из истории кабального холопства в XVI в. / В. М. Панеях // Вопросы экономики и классовых отношений в Русском государстве XII-XVII вв. : сб. ст. - М. ; Л. : Изд-во АНТСССР, 1960. - С. 101-128. - (Труды ЛОИИ АН СССР ; вып. 9).

41. Панеях, В. М. Кабальное холопство на Руси в XVI в. / В. М. Панеях. - М. : Наука, 1967. $160 \mathrm{c}$.

42. Победимова, Г. Л. О некоторых формах кредитования крестьян Иосифо-Волоколамского монастыря в первой половине XVI века / Г. Л. Победимова // Крестьянство и классовая борьба в феодальной России. - Л. : Наука, 1967. - С. 91-97. (Труды ЛОИИ АН СССР ; вып. 9).

43. Приходо-расходная денежная книга 1607 1608 г. // РГАДА. - Ф. 1192. - Оп. 2, ч. 1. - Д. 19. 289 л.

44. Сметанина, С. И. Хозяйственные книги Иосифо-Волоколамского монастыря в Российском государственном архиве древних актов (РГАДА) / С. И. Сметанина // История Волоколамского края и перспективы «Золотого наследия Руси» : сб. докл. науч.-практ. конф., 30 окт. 1998 г. - М. : РМАТ, 1999. C. $31-48$.
45. Смирнов, И. И. Восстание Болотникова 1606-1607 / И. И. Смирнов. - Л. : Государственное издательство политической литературы, 1951. 590 с. : ил.

46. Смирнов, И. И. Предвестники восстания Болотникова / И. И. Смирнов // Исторические записки. - 1946. - Т. 20. - С. 66-95.

47. Смолич, И. К. Русское монашество 9881917. Жизнь и учение старцев / И. К. Смолич - М. : Церковно-научный центр «Православная энциклопедия», 1997. - 297 с.

48. Тихомиров, М. Н. Монастырь - вотчинник XVI в. / М. Н. Тихомиров // Исторические записки. - 1938. - Т. 3. - С. 130-160.

49. Тихомиров, М. Н. Приходо-расходные книги Иосифо-Волоколамского монастыря 1606/07 г. / М. Н. Тихомиров, Б. Н. Флоря // Археографический ежегодник за 1966 год. - 1968. - С. 331-383.

50. Указ о запрещении пожизненного кабального холопства от 9 марта 1608 г. // Законодательные акты Русского государства второй половины XVI - первой половины XVII в. / под ред. Н. Е. Носова. - Л. : Наука, 1986. - С. 77.

51. Щепетов, К. Н. Сельское хозяйство в вотчинах Иосифо-Волоколамского монастыря в конце XVI в. / К. Н. Щепетов // Исторические записки. 1946. - T. 18. - C. 92-147.

\section{REFERENCES}

1. Bugrov A.V. Ssudnye operatsii russkikh monastyrey v XIV-XVII vv. [Loan Operations of Russian Monasteries in the $14^{\text {th }}-17^{\text {th }} \mathrm{c}$.]. Vestnik Banka Rossii [Bank of Russia Publications], 2004, no. 18 (742), pp. 31-35.

2. Vodarskiy Ya.E., Istomina E.G. Pravoslavnye monastyri Rossii i ikh rol $v$ razvitii kultury (XI nachalo $X X v$ v.) [Orthodox Monasteries of Russia and Their Role in the Development of Culture $\left(11^{\text {th }}-\right.$ Early $20^{\text {th }}$ c.)]. Moscow, Institut rossiyskoy istorii RAN, 2009. $546 \mathrm{p}$.

3. Grekov B.D. Krestyane na Rusi $s$ drevneyshikh vremen do serediny XVII v. V 2 t. T. 2 [Peasants in Russia from the Earliest Times to the Middle of the $17^{\text {th }}$ c. In 2 vols. Vol. 2]. Moscow, Izd-vo AN SSSR, 1954. 470 p.

4. Dadykina M.M. Kabaly Spaso-Prilutskogo monastyrya vtoroy poloviny XVI - XVII vv. Issledovanie. Teksty [Bondages of the Spaso-Prilutsky Monastery of the Second Half of the $16^{\text {th }}-17^{\text {th }}$ c. Study. Texts]. Moscow, Saint-Petersburg, Alyans-Arkheo Publ., 2011. 384 p.

5. Dyakonov M.A. Ocherki iz istorii selskogo naseleniya $v$ Moskovskom gosudarstve, XVI-XVII vv. [Essays on the History of the Rural Population in the 
Moscow State, $16^{\text {th }}-17^{\text {th }}$ c.]. Moscow, URSS Publ., 2011. 348 p. (Akademiya fundamentalnykh issledovaniy: istoriya) [Academy of Basic Research: History].

6. Zaemnaya kabala krestyanki Aleksandra Andreevicha Nagova s. Parfeneva Pelagei Ivanovoy docheri, Savelyevskoy zheny kelaryu Korniliyu na vzyatyy khleb vo vremya osady [Loan Bondage of a Peasant Woman of Alexander Andreevich Nagoy of Village Parfenevo, Pelageya Ivanova's Daughter, Saveley's Wife, to Cellarer Korniliy on the Bread Borrowed During the Siege]. Rossiyskiy gosudarstvennyy arkhiv drevnikh aktov [Russian State Archive of Ancient Acts], F. 1192 (JosephVolokolamsk Monastery), Op. 1, Part 4, D. 2540, L. 1.

7. Zaemnaya kabala osadnogo sideltsa monastyrskogo krestyanina Daniila Matveeva Kuznetsa zhitnomu startsu Korniliyu na vzyatyy monastyrskiy khleb [Loan Bondage of Besieged Man Monastic Peasant Daniil Matveev Kuznets to Granary Monk Korniliy on Borrowed Monastic Bread]. Rossiyskiy gosudarstvennyy arkhiv drevnikh aktov [Russian State Archive of Ancient Acts], F. 1192, Op. 1, Part 4, D. 2248, L. 1.

8. Zaemnaya kabala osadnogo sideltsa, posad slobody Andreya Kuryeva na vzyatyy khleb iz monastyrskikh zhitnits [Loan Bondage of Besieged Man of Posad Sloboda Andrey Kurev on the Bread Borrowed from the Monastic Granaries]. Rossiyskiy gosudarstvennyy arkhiv drevnikh aktov [Russian State Archive of Ancient Acts], F. 1192, Op. 1, Part 4, D. 2542, L. 1.

9. Zaemnye kabaly osadnogo sideltsa Bazhena Dmitrieva Yazykova kelaryu Korniliyu na vzyatyy khleb [Loan Bondages of Besieged Man Bazhen Dmitriev Yazykov to Cellarer Korniliy on Borrowed Bread]. Rossiyskiy gosudarstvennyy arkhiv drevnikh aktov [Russian State Archive of Ancient Acts], F. 1192, Op. 1, Part 4, D. 2529, L. 1-4.

10. Zaemnye kabaly osadnogo sideltsa, krestyanina Vnuka Zinovyevicha Tyutcheva seltsa Kurova Matveya Lukyanova na vzyatyy khleb iz monastyrskikh zhitnits [Loan Bondages of Besieged Man Peasant of Vnuk Zinovevich Tyutchev Matvey Lukyanov of Village Kurovo on the Bread Borrowed from Monastic Granaries]. Rossiyskiy gosudarstvennyy arkhiv drevnikh aktov [Russian State Archive of Ancient Acts], F. 1192, Op. 1, Part 4, D. 2543, L. 1-5.

11. Zaemnye kabaly osadnykh sideltsev volotskikh posadnykh lyudey sapozhnogo mastera Fedora Vasilyeva i rassylshchika Frola Vasilyeva kelaryu Korniliyu na vzyatyy khleb [Loan Bondages of Besieged People - Volok's Posad People Shoemaker Fedor Vasilev and Mailer Frol Vasilev - to Cellarer Korniliy on Borrowed Bread]. Rossiyskiy gosudarstvennyy arkhiv drevnikh aktov [Russian
State Archive of Ancient Acts], F. 1192, Op. 1, Part 4, D. 2531, L. 1 .

12. Zaemnye kabaly osadnykh sideltsev volotskikh posadskikh lyudey - kelaryu Korniliyu na vzyatyy khleb [Loan Bondages of Besieged People Volok's Posad People - to Cellarer Korniliy on Borrowed Bread]. Rossiyskiy gosudarstvennyy arkhiv drevnikh aktov [Russian State Archive of Ancient Acts], F. 1192, Op. 1, Part 4, D. 2535, L. 1-3.

13. Zaemnye kabaly osadnykh sideltsev krestyan i delovykh lyudey Aleksandra Andreevicha Nagova - kelaryu Korniliyu na vzyatyy khleb [Loan Bondages of Besieged People-Aleksandr Andreevich Nagoy's Peasants and Business People - to Cellarer Korniliy on Borrowed Bread]. Rossiyskiy gosudarstvennyy arkhiv drevnikh aktov [Russian State Archive of Ancient Acts], F. 1192, Op. 1, Part 4, D. 2545 , L. $1-6$.

14. Zaemnye kabaly osadnykh sideltsev krestyan i posadskikh lyudey - kelaryu Korniliyu na vzyatyy khleb [Loan Bondages of Besieged People Peasants and Posad People - to Cellarer Korniliy on Borrowed Bread]. Rossiyskiy gosudarstvennyy arkhiv drevnikh aktov [Russian State Archive of Ancient Acts], F. 1192, Op. 1, Part 4, D. 2538, L. 1-4.

15. Zaemnye kabaly osadnykh sideltsev krestyan Mikhaila Dmitrievicha Telegina, krestyan Grigoriya Stupishina s. Smolinskogo - kelaryu Korniliyu na vzyatyy khleb [Loan Bondages of Besieged People - Mikhail Dmitrievich Telegin's Peasants, Grigoriy Stupishin's Peasants of Village Smolinskoe - to Cellarer Korniliy on Borrowed Bread]. Rossiyskiy gosudarstvennyy arkhiv drevnikh aktov [Russian State Archive of Ancient Acts], F. 1192, Op. 1, Part 4, D. 2537, L. 1-16.

16. Zaemnye kabaly osadnykh sideltsev krestyan Mikhaila Telegina kelaryu Korniliyu na vzyatyy khleb [Loan Bondages of Besieged People Mikhail Telegin's Peasants - to Cellarer Korniliy on Borrowed Bread]. Rossiyskiy gosudarstvennyy arkhiv drevnikh aktov [Russian State Archive of Ancient Acts], F. 1192, Op. 1, Part 4, D. 2544, L. 1-4.

17. Zaemnye kabaly osadnykh sideltsev krestyan Moskovskogo Novodevichego monastyrya kelaryu Korniliyu na vzyatyy khleb [Loan Bondages of Besieged People - Peasants of Moscow Novodevichiy Monastery - to Cellarer Korniliy on Borrowed Bread]. Rossiyskiy gosudarstvennyy arkhiv drevnikh aktov [Russian State Archive of Ancient Acts], F. 1192, Op. 1, Part 4, D. 2534, L. 1-4. 18. Zaemnye kabaly osadnykh sideltsev krestyan Novodevichego monastyrya der. Krotovo, Korotymnovo, Oleshina, s. Spasskogo, s. Pokoina, s. Kozino - kelaryu Korniliyu na vzyatyy khleb [Loan Bondages of Besieged People - Peasants of Moscow Novodevichy Monastery of Villages Krotovo, 
Korotymnovo, Oleshino, Spasskoe, Pokoino, Kozino to Cellarer Korniliy on Borrowed Bread]. Rossiyskiy gosudarstvennyy arkhiv drevnikh aktov [Russian State Archive of Ancient Acts], F. 1192, Op. 1, Part 4, D. 2541, L. 1-13.

19. Zaemnye kabaly osadnykh sideltsev krestyan Fedora Iudovicha Khripunova - kelaryu Korniliyu na vzyatyy khleb [Loan Bondages of Besieged People - Peasants of Fedor Iudovich Khripunov - to Cellarer Korniliy on Borrowed Bread]. Rossiyskiy gosudarstvennyy arkhiv drevnikh aktov [Russian State Archive of Ancient Acts], F. 1192, Op. 1, Part 4, D. 2533, L. 1-8.

20. Zaemnye kabaly osadnykh sideltsev moskovskogo streltsa Semena Sergeeva i volotskikh posadskikh lyudey - kelaryu Korniliyu na vzyatyy khleb [Loan Bondages of Besieged People-Moscow Strelets Semen Sergeev and Volok's Posad People - to Cellarer Korniliy on Borrowed Bread]. Rossiyskiy gosudarstvennyy arkhiv drevnikh aktov [Russian State Archive of Ancient Acts], F. 1192, Op. 1, Part 4, D. 2539, L. 1-7.

21. Zaemnye kabaly osadnykh sideltsev svyashchennosluzhiteley, volotskikh posadnykh lyudey, krestyan Andreya Timofeevicha Bykasova s. Teplova - kelaryu Korniliyu na vzyatyy khleb [Loan Bondages of Besieged People - Clerics, Volok's Posad People, Peasants of Andrey Timofeevich Bykasov of Village Teplovo - to Cellarer Korniliy on Borrowed Bread]. Rossiyskiy gosudarstvennyy arkhiv drevnikh aktov [Russian State Archive of Ancient Acts], F. 1192, Op. 1, Part 4, D. 2536, L. 1-55.

22. Zaemnye kabaly osadnykh sideltsev detey boyarskikh - volochanina Melentiya Konstantinova, dmitrovtsa Grigoriya Prokofeva syna Savina, ruzhan bratyev Kurvinykh s tov. - kelaryu Korniliyu na vzyatyy khleb [Loan Bondages of Besieged People of Boyar Children - Volok Man Melentiy Konstantinov, Dmitrov Man Grigoriy Prokofev, Sava's Son, Ruzha People Kurvin Brothers with Friends - to Cellarer Korniliy on Borrowed Bread]. Rossiyskiy gosudarstvennyy arkhiv drevnikh aktov [Russian State Archive of Ancient Acts], F. 1192, Op. 1, Part 4, D. 2532. L. 1-13.

23. Zaemnye kabaly osadnykh sideltsev kelaryu Korniliyu i zhitnichnomu startsu Leonidu na vzyatyy khleb [Loan Bondages of Besieged People to Cellarer Korniliy and Granary Monk Leonid on Borrowed Bread]. Rossiyskiy gosudarstvennyy arkhiv drevnikh aktov [Russian State Archive of Ancient Acts], F. 1192, Op. 1, Part 4, D. 2527. L. 1-51.

24. Zaemnye kabaly osadnykh sideltsev krestyan Aleksandra Andreevicha Nagova s. Parfeneva kelaryu Korniliyu na vzyatyy khleb [Loan Bondages of Besieged People - Peasants of Aleksander Andreevich Nagoy of Village Parfenevo - to Cellarer
Korniliy on Borrowed Bread]. Rossiyskiy gosudarstvennyy arkhiv drevnikh aktov [Russian State Archive of Ancient Acts], F. 1192, Op. 1, Part 4, D. 2530, L. 1-13.

25. Zaemnye kabaly osadnykh sideltsev monastyrskim vlastyam na zanyatyy vo vremya osady monastyrya khleb [Loan Bondages of Besieged People to the Monastic Administration on the Bread Borrowed during the Siege]. Rossiyskiy gosudarstvennyy arkhiv drevnikh aktov [Russian State Archive of Ancient Acts], F. 1192, Op. 1, Part 4, D. 2526, L. 1-199.

26. Zaemnye kabaly osadnykh sideltsevsvyashchennosluzhiteley kelaryu Korniliyu i zhitnichnomu startsu Leonidu na vzyatyy khleb [Loan Bondages of Besieged Clerks to Cellarer Korniliy and Garnery Monk Leonid on Borrowed Bread]. Rossiyskiy gosudarstvennyy arkhiv drevnikh aktov [Russian State Archive of Ancient Acts], F. 1192, Op. 1, Part 4, D. 2528. L. 1-6.

27. Zimin A.A. Krupnaya feodalnaya votchina $i$ sotsialno-politicheskaya borba $v$ Rossii $v$ kontse $X V-X V I v$. [Large Feudal Fiefdom and Socio-Political Struggle in Russia in the Late $15^{\text {th }}-16^{\text {th }} \mathrm{c}$. $]$. Moscow, Nauka Publ., 1977. 356 p.

28. Zimin A.A. O diplomatike zhalovannykh gramot Iosifo-Volokolamskogo monastyrya XVI v. [On the Diplomacy of Charters of the JosephVolokolamsk Monastery of the $16^{\text {th }} \mathrm{c}$.]. Aktovoe istochnikovedenie: sb. st. [Act Source Study. Collection of Articles]. Moscow, 1979, pp. 164-178.

29. Kabalnaya kniga 1609 g. [Bondage Book of 1609]. Nauchno-istoricheskiy arkhiv SanktPeterburgskogo instituta istorii RAN [Scientific and Historical Archive of St. Petersburg Institute of History of RAS], Collection 115, Op. 1, D. 1037, 1591.

30. Kashtanov S.M. Moskovskoe tsarstvo $i$ Zapad. Istoriograficheskie ocherki [Moscow Tsardom and the West. Historiographical Essays]. Moscow, Izd-vo Universiteta Dmitriya Pozharskogo, 2015. $461 \mathrm{p}$.

31. Kashtanov S.M. Ocherki russkoy diplomatiki [Essays of Russian Diplomacy]. Moscow, Nauka Publ., $1970.502 \mathrm{p}$.

32. Kirichenko L.A. Aktovyy material TroitseSergieva monastyrya 1584-1641 gg. kak istochnik po istorii zemlevladeniya $i$ hozyaystva [The Act Material of the Trinity Sergius Monastery of 15841641 as a Source of the History of Land Ownership and Economy]. Moscow, Izd-vo RGGU, 2006. 288 p.

33. Klyuchevskiy V.O. Proiskhozhdenie krepostnogo prava v Rossii [Origin of Serfdom in Russia]. Sobranie sochineniy. V 9 t. T. 8 [Collected Works. In 9 vols. Vol. 8]. Moscow, Mysl Publ., 1990, pp. 120-193.

34. Tikhomirov M.N., Zimin A.A., eds. Kniga klyuchey $i$ dolgovaya kniga Iosifo-Volokolamskogo 
monastyrya XVI v. [The Book of Keys and the Debt Book of the Joseph-Volokolamsk Monastery of the $16^{\text {th }}$ c.]. Moscow, Leningrad, Izd-vo AN SSSR, 1948. $172 \mathrm{p}$.

35. Koretskiy V.I. Zakreposhchenie krestyan $i$ klassovaya borba $v$ Rossii [Enslavement of Peasants and Class Struggle in Russia]. Moscow, Nauka Publ., $1970.366 \mathrm{p}$.

36. Mankov A.G. Khozyaystvennye knigi monastyrskikh votchin XVI v. kak istochnik po istorii krestyan [Economic Books of Monastic Estates of the $16^{\text {th }}$ Century as a Source for the History of Peasants]. Problemy istochnikovedeniya [Issues of Source Studies], 1955, iss. 4, pp. 286-306.

37. Mukhina Yu.Yu. Kharakteristika polozheniya krestyan i kholopov v Rossii vo vtoroy polovine XVIXVII vv. [Characteristics of the Situation of Peasants and Serfs in Russia in the Second Half of the $16^{\text {th }}-17^{\text {th }} \mathrm{c}$.] Vestnik Moskovskogo gosudarstvennogo gumanitarnogo universiteta im. M.A. Sholokhova. Seriya "Istoriya i politologiya", 2012, no. 2, pp. 5-14.

38. Pavlov-Silvanskiy N.P. Gosudarevy sluzhilye lyudi. Lyudi kabalnye i dokladnye [Sovereign serving People. Bonded and Reporting People]. Tipografiya M.M. Stasyulevicha, 1909. 336 p.

39. Paneyah V.M. Dobrovolnoe holopstvo v zakonodatelstve XVI-XVII vv. (1550-1649 gg.) [Voluntary Servitude in the Legislation of the $16^{\text {th }}$ $17^{\text {th }}$ c. (1550-1649)]. Issledovaniya po sotsialnopoliticheskoy istorii Rossii: sb. st. pamyati B.A. Romanova [Research on the Socio-Political History of Russia. Collection of Articles in Memory of B.A. Romanov]. Leningrad, Nauka Publ., 1971, pp. 198216. (Trudy LOII AN SSSR [Proc. of LBIHAS USSR]; iss. 12).

40. Paneyah V.M. Iz istorii kabalnogo holopstva v XVI v. [From the History of Bonded Servitude in the $16^{\text {th }}$ c.]. Voprosy ekonomiki i klassovykh otnosheniy $v$ Russkom gosudarstve XII-XVII vv.: sb. st. [Issues of Economics and Class Relations in the Russian State, $12^{\text {th }}-17^{\text {th }}$ c. Collected Articles]. Moscow, Leningrad, Izd-vo AN SSSR, 1960, pp. 101-128. (Trudy LOII AN SSSR [Proc. of LBIHAS USSR]; iss. 9).

41. Paneyah V.M. Kabalnoe kholopstvo na Rusi $v X V I v$. [Bonded Servitude in Russia in the $16^{\text {th }} \mathrm{c}$.]. Moscow, Nauka Publ., 1967. 160 p.

42. Pobedimova G.L. O nekotorykh formakh kreditovaniya krestyan Iosifo-Volokolamskogo monastyrya $\mathrm{v}$ pervoy polovine XVI veka [On Some Forms of Lending Peasants of the Joseph-Volokolamsk Monastery in the First Half of the $16^{\text {th }} \mathrm{c}$.]. Krestianstvo $i$ klassovaya borba $v$ feodalnoy Rossii [Peasantry and Class Struggle in Feudal Russia]. Leningrad, Nauka
Publ., 1967, pp. 91-97. (Trudy LOII AN SSSR [Proceedings of LBIH AS USSR]; iss. 9).

43. Prikhodo-raskhodnaya denezhnaya kniga 1607-1608 g. [Account Cash Book of 1607-1608]. Rossiyskiy gosudarstvennyy arkhiv drevnikh aktov [Russian State Archive of Ancient Acts], F. 1192, Op. 2, Part 1, D. 19, 2891.

44. Smetanina S.I. Khozyaystvennye knigi Iosifo-Volokolamskogo monastyrya v Rossiyskom gosudarstvennom arkhive drevnikh aktov (RGADA) [Economic Books of the Joseph-Volokolavsk Monastery in the Russian State Archive of Ancient Acts (RSAAD)]. Istoriya Volokolamskogo kraya $i$ perspektivy «Zolotogo naslediya Rusi»: sb. dokl. nauch.-prakt. konf., $30 \mathrm{okt} .1998 \mathrm{~g}$. [The History of Volokolamsk Region and Prospects of the Golden Heritage of Russia. Collection of Reports of Scientific and Practical Conference. Volokolamsk, October, 30, 1998]. Moscow, RMAT Publ., 1999, pp. 31-48.

45. Smirnov I.I. Vosstanie Bolotnikova 16061607 [The Bolotnikov Uprising of 1606-1607]. Leningrad, Gosudarstvennoe izdatelstvo politicheskoy literatury, 1951.590 p., il.

46. Smirnov I.I. Predvestniki vosstaniya Bolotnikova [Harbingers of the Bolotnikov Uprising]. Istoricheskie zapiski, 1946, vol. 20, pp. 66-95.

47. Smolich I.K. Russkoe monashestvo 9881917. Zhizn i uchenie startsev [Russian Monasticism. Life and Teachings of Monks]. Moscow, Tserkovnonauchnyy tsentr "Pravoslavnaya entsiklopediya", 1997. 297 p.

48. Tikhomirov M.N. Monastyr - votchinnik XVI v. [Monastery is the Manor of the $\left.16^{\text {th }} \mathrm{c}.\right]$. Istoricheskie zapiski, 1938, vol. 3, pp. 130-160.

49. Tikhomirov M.N., Florya B.N. Prikhodoraskhodnye knigi Iosifo-Volokolamskogo monastyrya 1606/07 g. [Account Cash Books of the Joseph-Volokolamsk Monastery of 1606/07]. Arkheograficheskiy ezhegodnik za 1966 god, 1968, pp. 331-383.

50. Ukaz o zapreshchenii pozhiznennogo kabalnogo holopstva ot 9 marta $1608 \mathrm{~g}$. [The Decree on the Prohibition of a Life-long Servitude Dated March 9, 1608]. Nosov N.E., ed. Zakonodatelnye akty Russkogo gosudarstva vtoroy poloviny XVI-pervoy poloviny XVII v. [Legislative Acts of the Russian State of the Second Half of the $16^{\text {th }}$ - the First Half of the $17^{\text {th }}$ c.]. Leningrad, Nauka Publ., 1986, p. 77.

51. Shchepetov K.N. Selskoe khozyaystvo v votchinakh Iosifo-Volokolamskogo monastyrya $\mathrm{V}$ kontse XVI v. [Agriculture in the Patrimonies of the Joseph-Volokolamsk Monastery in the Late $16^{\text {th }} \mathrm{c}$.]. Istoricheskie zapiski, 1946, vol. 18, pp. 92-147. 


\section{Information about the Author}

Evgeniya S. Tseluykina, Master Student, Department of National and World History, Archaeology, Volgograd State University, Prosp. Universitetsky, 100, 400062 Volgograd, Russian Federation, tseluikina.eugenia@gmail.com, https://orcid.org/0000-0003-4381-287X

\section{Информация об авторе}

Евгения Сергеевна Целуйкина, магистрант кафедры отечественной и всеобщей истории, археологии, Волгоградский государственный университет, просп. Университетский, 100, 400062 г. Волгоград, Российская Федерация, tseluikina.eugenia@gmail.com, https://orcid.org/0000-0003-4381-287X 